\title{
4. MULTICHANNEL SEISMIC SURVEY OF THE CENTRAL IZU-BONIN ARC ${ }^{1}$
}

\author{
Brian Taylor, Gregory Moore, Adam Klaus, Martha Systrom, \\ Patricia Cooper, and Mary MacKay²
}

\section{INTRODUCTION}

Multichannel seismic (MCS) data were collected in the central Izu-Bonin island arc in preparation for Legs 125 and 126 of the Ocean Drilling Program, and as part of our continuing research into the evolution of intraoceanic arc-trench systems (Fig. 1). Our seismic investigation focused on the processes of arc, forearc, and backarc formation, tectonics, and sedimentation. In the forearc basin, the MCS data provide insights into the nature and mode of basin formation, lithospheric flexure that results from arc volcano loading, and forearc sedimentation processes and evolution. Major issues addressed by the MCS survey in the arc/backarc region include the nature and style of arc volcanism and backarc rift-basin sedimentation, faulting, and volcanism.

For an overview of the tectonic evolution of the Izu-Bonin Arc, see the "Introduction" chapter (this volume). In this paper we present the processed MCS data from our surveys of the Sumisu Rift (Profiles 3-6, 8, 9, 13, and 14) and the arc to outerarc high portion of the forearc (Profiles 1-5 and 8-14; Fig. 2). Interpretations of the trench-slope MCS data appear in Horine et al. (in press). Papers presenting our interpretation of the backarc rift and forearc basin MCS data are in preparation. Detailed correlations of the MCS data and the Leg 126 drilling results are presented in the "Seismic Stratigraphy" sections of each site chapter in this volume.

\section{DATA ACQUISITION AND PROCESSING}

We collected over $3000 \mathrm{~km}$ of 96-channel seismic data from the Izu-Bonin Arc during two cruises of the Fred Moore (FM 3505 , 17 June to 7 July 1987; FM 3507, 4-16 August 1987; see Fig. 2). The seismic source consisted of a tuned array of six Bolt air guns (total $=1065$ in. $^{3}$ ) and a single large air gun $\left(2000\right.$ in. $\left.^{3}\right)$, which resulted in sources that ranged from 1065 to 3065 in. ${ }^{3}$. Shot intervals ranged from 16 to $67 \mathrm{~m}$ (average $\sim 35 \mathrm{~m}$ ) depending on ship speed and shot repetition rate. The streamer was configured into 96 groups consisting of 40 hydrophones each. Groups were separated by $33.3 \mathrm{~m}$ with a near offset (channel 96) of $170 \mathrm{~m}$ and a far offset (channel 1) of $3337 \mathrm{~m}$. Loran $\mathrm{C}$ and the global positioning system (GPS) provided navigation data. The 2-ms-sampled seismic data were band-pass filtered at $5 \mathrm{~Hz}$ (24 dB/octave) to $100 \mathrm{~Hz}$ (54 dB/octave) and recorded on a GUS 4200 system in demultiplexed SEGD format using an integer floating point gain.

We processed the data at the University of Tulsa on a VAX 11/750 equipped with a Phoenix processing system (Seismograph Service Corporation). The processing sequence began by resampling the data to $4 \mathrm{~ms}$ and removing noisy traces and bad shots. Next, the source-receiver geometry was defined from the

\footnotetext{
${ }^{1}$ Taylor, B., Fujioka, K., et al., 1990. Proc. ODP, Init. Repts., 126: College Station, TX (Ocean Drilling Program).

2 All at Hawaii Institute of Geophysics, University of Hawaii at Manoa, 2525 Correa Road, Honolulu, HI 96822.
}

navigation and the data were sorted into $16.7-\mathrm{m}$ common midpoints. After velocity analysis, normal moveout (NMO), and muting of severe NMO stretch, the data were stacked ( $\sim 48$ fold). The data were then deconvolved $(200 \mathrm{~ms}$ operator, with $3 \%$ white noise added), time-varying band-pass filtered, migrated using finite difference migration, band-pass filtered at 6-10-50$60 \mathrm{~Hz}$, gained using $500-\mathrm{ms}$ automatic gain control, muted to water bottom, and plotted.

\section{FOREARC BASEMENT}

Figures 3 (in back pocket) and 4-6 show our migrated MCS profiles from the volcanic arc to the outer-arc high. The acoustic basement surface is strongly reflective on the outer-arc high, but it becomes less so beneath the forearc basin where the velocity contrast with the deep basin sediments is less. Basement cannot be followed west to the volcanic front, primarily because of the water-bottom multiple reflection. The basement is seismically stratified, with strong reflectors that dip both east and west beneath the outer-arc high. The high is presumed to be formed of Eocene boninites and island-arc tholeiites, similar to those cropping out on the Bonin Islands along strike to the south. The basement surface has significant relief, commonly $500-1000 \mathrm{~m}$, but more than $2000 \mathrm{~m}$ in places. The outer-arc basement high is bounded on the west by a series of west-dipping buried escarpments that are probably normal faults. Further west, basement blocks form numerous ridges with intervening troughs beneath the forearc sedimentary basin. Several of the troughs appear to be half grabens (e.g., Profile 14, 1300$1600 \mathrm{Z}$ near $5 \mathrm{~s}$; see Fig. 3, in back pocket). The strong east-dipping reflector within the basement at $1600-1700 \mathrm{Z}$ on Profile 14 (Fig. 3, in back pocket) may be from a crustal detachment surface. Profile $2 / 3$ crossed the northern flank of a large buried seamount at $0500-0600 \mathrm{Z}$ (Fig. 3, in back pocket). Frontal-arc basement highs, spaced about $100 \mathrm{~km}$ apart, are present east of Aoga Shima, Sumisu Jima, and Tori Shima. Our survey crossed only the smallest of these highs (Profile 10, Fig. 4), which are reflected by shallow bathymetry (Fig. 2). Where dredged further south $\left(25^{\circ}-30^{\circ} \mathrm{N}\right)$ by the Geological Survey of Japan, these highs yield upper Eocene volcaniclastics (M. Yuasa, pers. comm., 1987). These highs were probably formed by late Eocene and early Oligocene arc volcanoes.

\section{FOREARC SEDIMENTS}

The forearc sedimentary section can be subdivided into three major seismic-stratigraphic units. The first caps (and is restricted to) the outer-arc high basement. It is a thin, finely layered, often-eroded unit of presumed (hemi-) pelagic sediments. It is best seen on Profile 5 east of $0245 Z$ (Fig. 3, in back pocket). Further east, the inner-trench slope is nearly devoid of sediments (e.g., Profile 14 of Fig. 3, in back pocket), except where ponded around the serpentinite seamounts at $5-6 \mathrm{~km}$ water depth (Fig. 2). The second unit forms the bulk of the forearc basin sedimentary fill. It is characterized by strong, continuous, subparallel reflectors, typical of turbidites, which lap onto the basement highs (e.g., 0700-0900Z on Profile 2; see Fig. 3, in back pocket). In areas of 


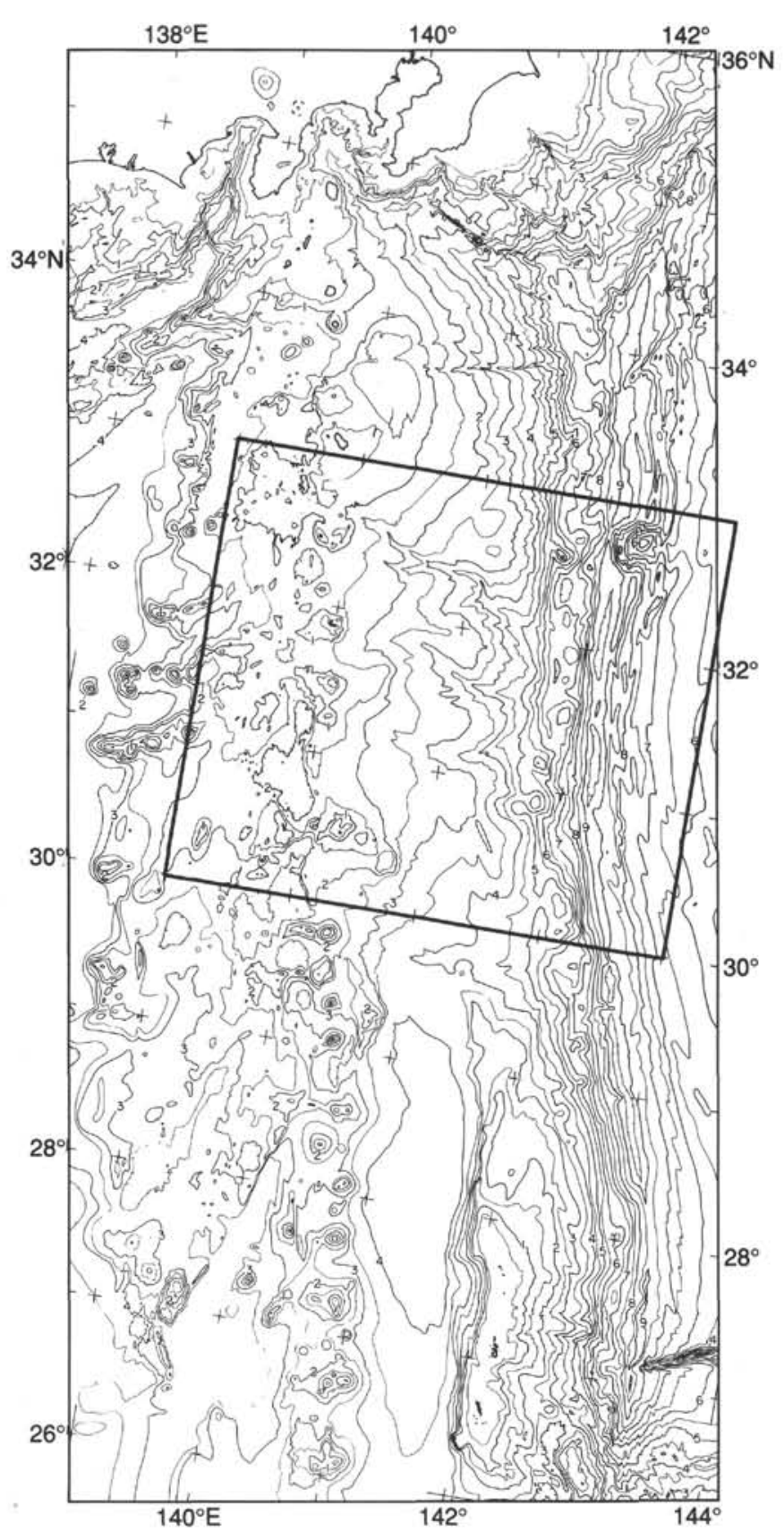

Figure 1. Bathymetry of the Izu-Bonin Arc at 500-m contour intervals showing the area (boxed) of our MCS survey and Figure 2.

deep basement depressions such as the previously discussed example, there is a lower subunit that is separated from the main upper unit by an angular unconformity. The MCS data show that normal faulting is pervasive throughout the entire unit. The third unit unconformably overlies the two lower units; in the center of the basin it is less faulted than the underlying unit and is characterized by discontinuous reflectors of varying amplitude, with migrating sediment packages indicative of channel cut and fill. This presumed hemipelagic unit is itself cut by major submarine channels and canyons (Figs. 3 [in back pocket] and 4). The least-eroded section is seen on Profile 4 (Fig. 3, in back pocket), which traverses an intercanyon high (Fig. 2). The unit thickens to the west toward the arc volcanoes. The reflectors increase in continuity and amplitude, presumably as a result of the coarsening volcaniclastic facies. Loading by the arc volcanoes appears to have flexed the forearc lithosphere, creating a proximal moat (filled with the volcaniclastic sediments) and an arch (onto which the sediments lap). This is particularly evident on the three northern profiles (Profiles 1-3, Fig. 3, in back pocket), but it can also be seen on Profile 13 (Fig. 6). The sedimentary sections in the moat and on the arch are cut by normal faults.

\section{SUMISU RIFT}

Figure 7 shows the detailed location, and Figures 8 and 9 show variable-area plots of our migrated MCS profiles across the Sumisu Rift and its margins. Figure 10 (in back pocket) shows wiggle-trace plots of the same data as Figure 8, but at less vertical exaggeration ( $\mathrm{VE}=2.1$ ). The seismic stratification of the pre-rift margins and "basement" of the 30-40-km-wide rift is highly variable as a result of significant syn-rift normal faulting and volcanism. The presumed arc-proximal, volcaniclastic, pre-rift section is often difficult to distinguish from the poorly stratified early syn-rift sediments because of this overprinting tectonism. Only the late syn-rift stage, strong, subparallel reflectors are easily correlated throughout the basin. These presumed volcaniclastic turbidites are offset by active normal faults. Fault offsets and reflector dips increase with depth, indicating syndepositional faulting.

The rift-basin development and sedimentation is fault controlled. Most of the intra-rift and rift-margin volcanism is also fault localized. Sumisu Rift is bounded on the east by a major fault zone (see Profiles 14 and 3-6, Figs. 8 and 10 [in back pocket]). To the east of this master fault zone, the arc margin has been uplifted, exposing pre-rift arc volcaniclastics. The lack of footwall uplift on Profile 6 may be the result of loading by the nearby arc volcano. In the south, on Profile 13, the master fault zone and rift-flank uplift is on the west side of the rift (Figs. 8 and 10 [in back pocket]). The transfer zone between the two opposing master fault systems is located at and south of Profile 14. It is a relay zone of distributed normal faulting rather than an oblique slip zone (see Profile 8, Fig. 8). Away from the master fault zones the pre-rift section gradually rises up and out of the basin, as seen on Profiles 13, 14, and 3. Further north, two antithetic fault zones have downdropped the western margin, producing a more symmetric rift profile (see Profiles 4-6, Fig. 8). On all of the east-west profiles, there is an inner-rift graben of maximum subsidence on the eastern side of the rift. This inner rift has been intruded by an en echelon volcanic ridge (Fig. 4) that was crossed on Profiles 5 and 8 (Figs. 8 and 9).

\section{ACKNOWLEDGMENTS}

This work was supported by NSF grants OCE86-14687 to B. Taylor and OCE-8700826 and OCE-8996141 to G. Moore. The authors would like to thank the officers, crew, and technicians of the Fred Moore as well as E. W. Behrems, R. Horine, Y. Nakamura, Y. Nogi, and Y. Okamura for their help in acquiring the seismic data at sea. This is HIG Contribution No. 2200.

\section{REFERENCES}

Horine, R. L., Moore, G. F., and Taylor, B., in press. Structure of the Outer Izu-Bonin Forearc from reflection seismic profiling and gravity modeling. In Fryer, P., Pearce, J., Stokking, L. B., et al., Proc. ODP Init. Repts., 125: College Station, TX (Ocean Drilling Program).

\section{Ms 126A-105}




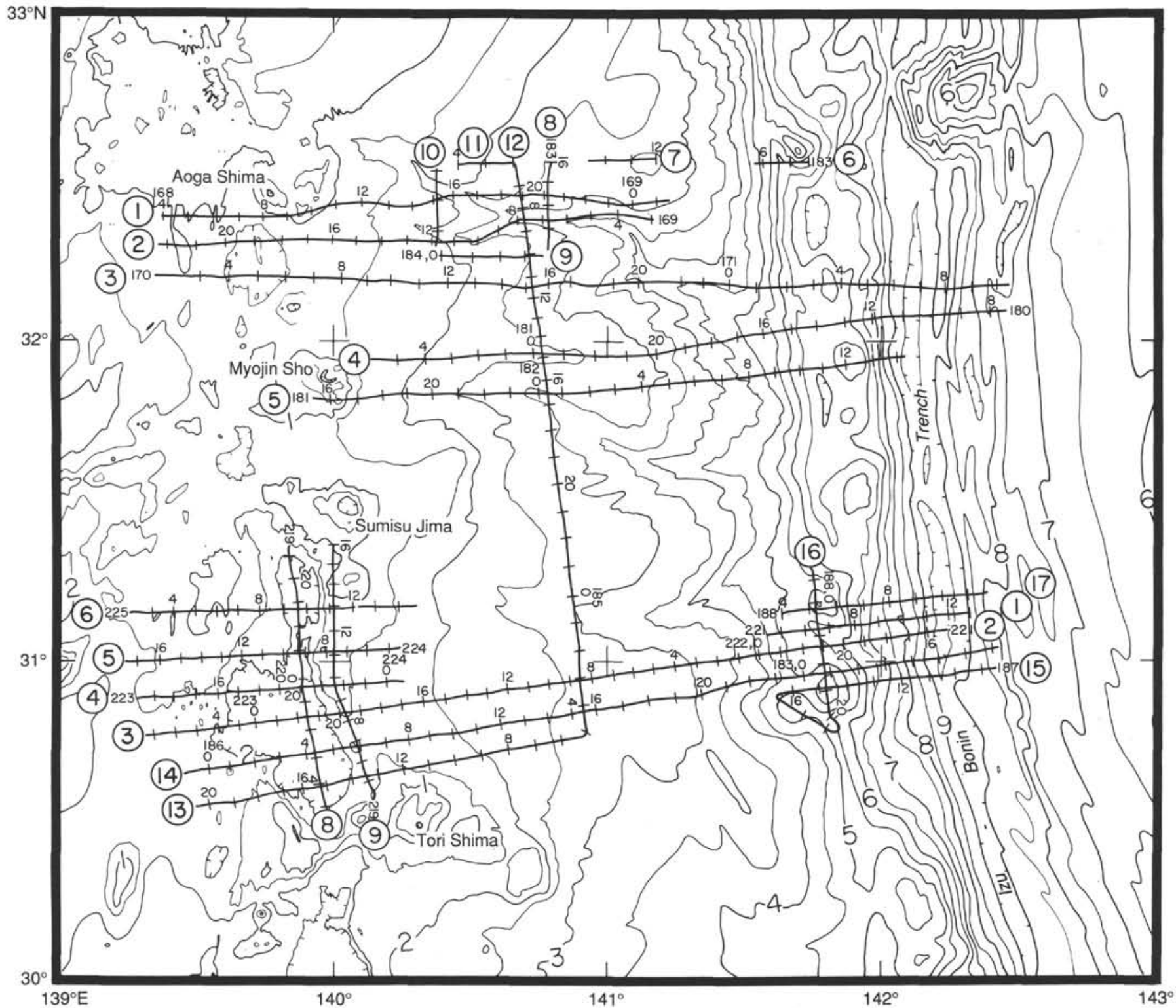

Figure 2. Track chart of the 1987 Fred Moore cruises 3505 and 3507 showing the location of MCS Profiles 1-17 (cruise 3505) and 1-6, 8, and 9 (cruise 3507). Tick marks every hour are annotated every $4 \mathrm{hr}$ along track. The Julian Day is annotated at the beginning of every new track segment and at the beginning of each day. The contour interval is $0.5 \mathrm{~km}$. 
B. TAYLOR ET AL.
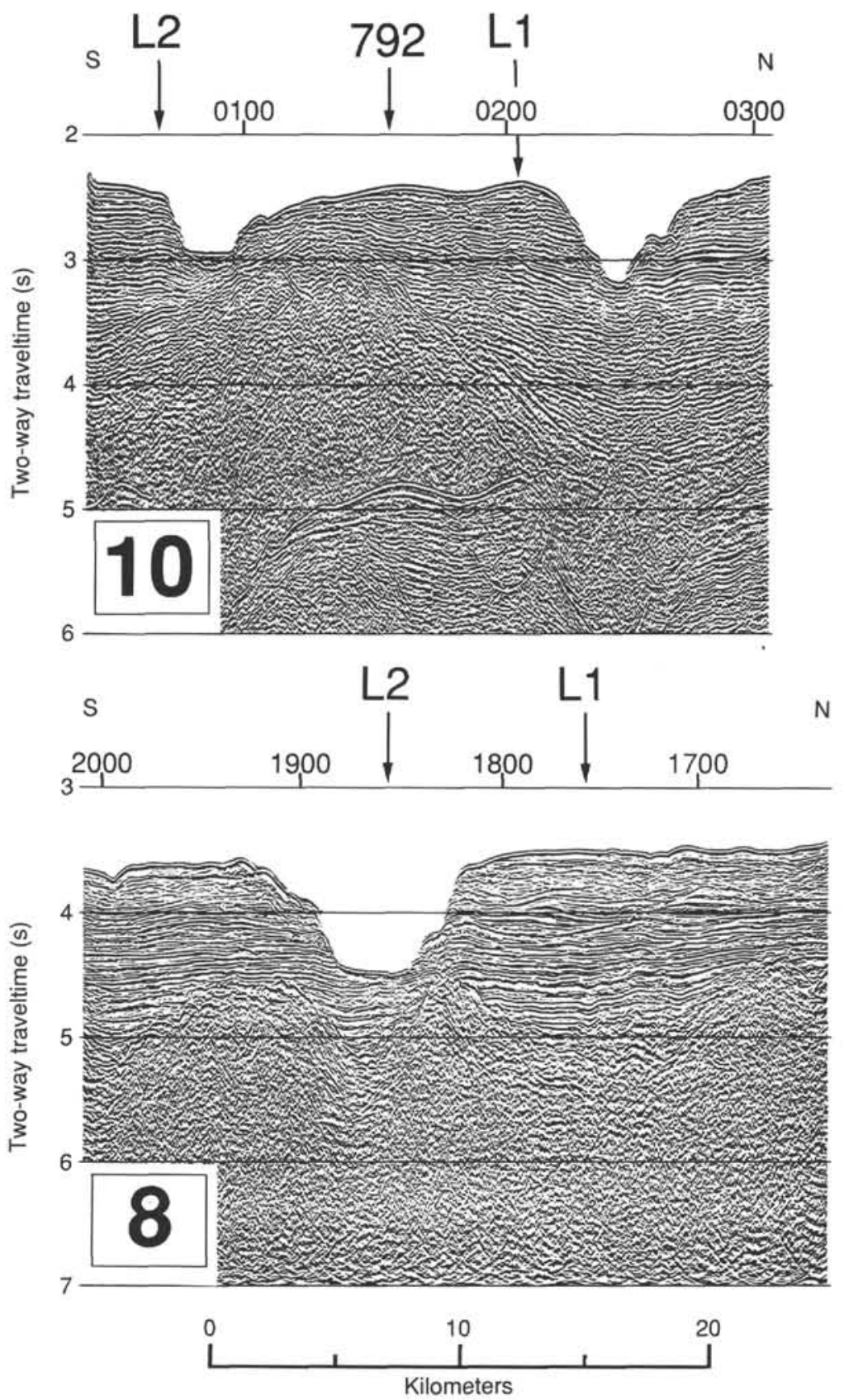

Figure 4. MCS Profiles 8 and 10 across Aoga Shima Canyon. VE $=6.7$. See Figure 2 for location. 

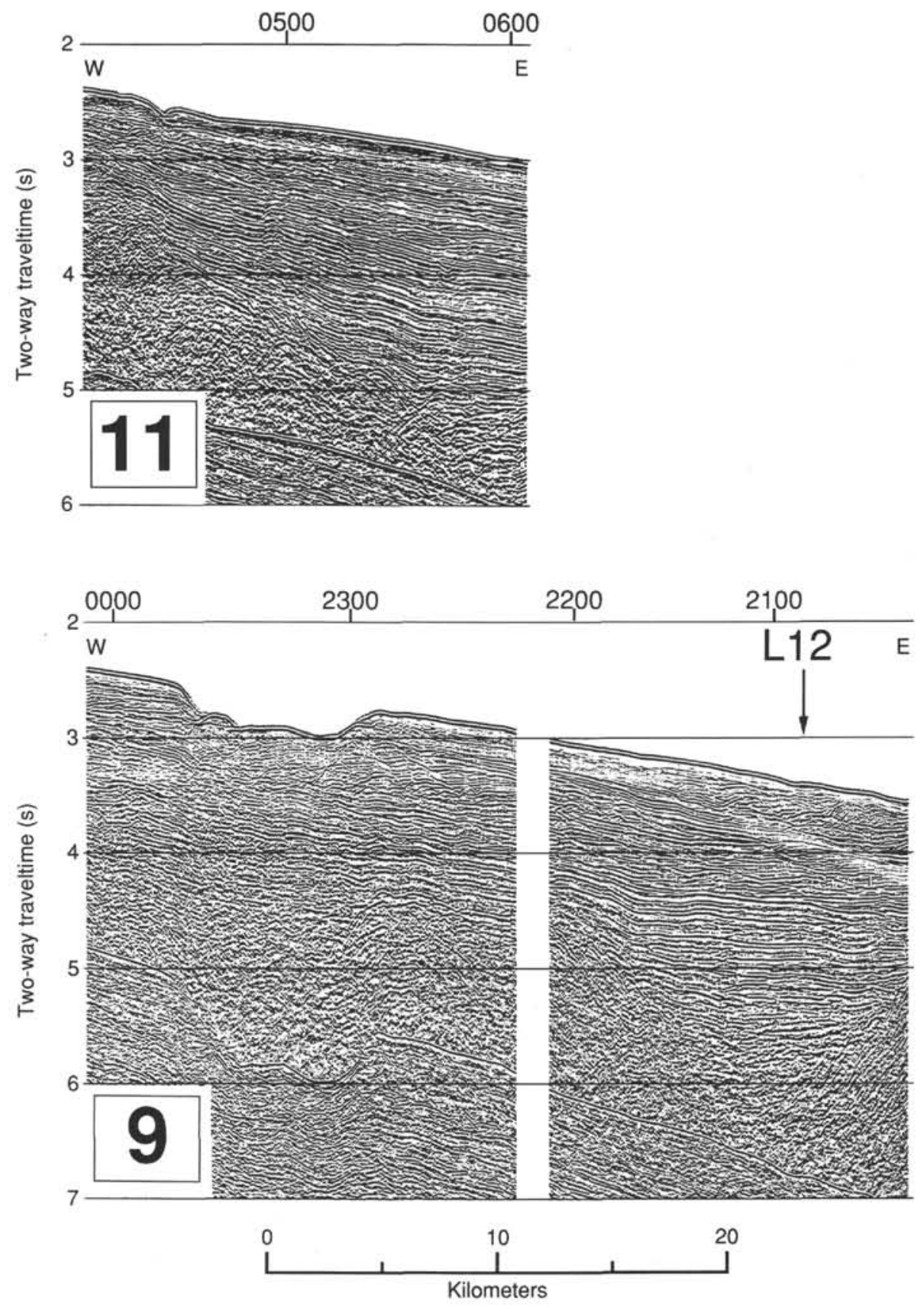

Figure 5. MCS Profiles 9 and 11. VE $=6.7$. See Figure 2 for location. 


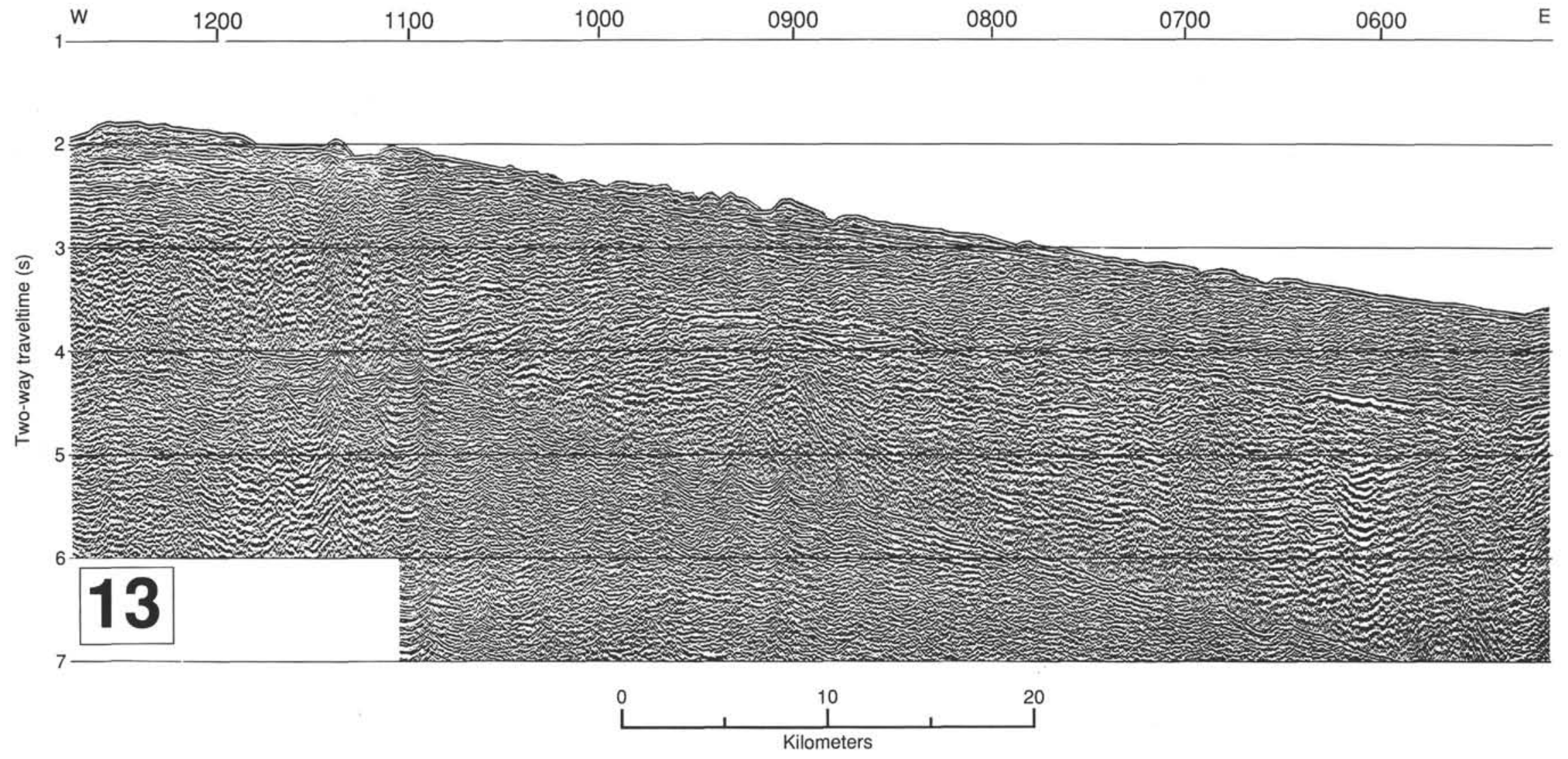

Figure 6. MCS Profile 13 across the inner forearc. VE $=6.7$. See Figure 2 for location. 


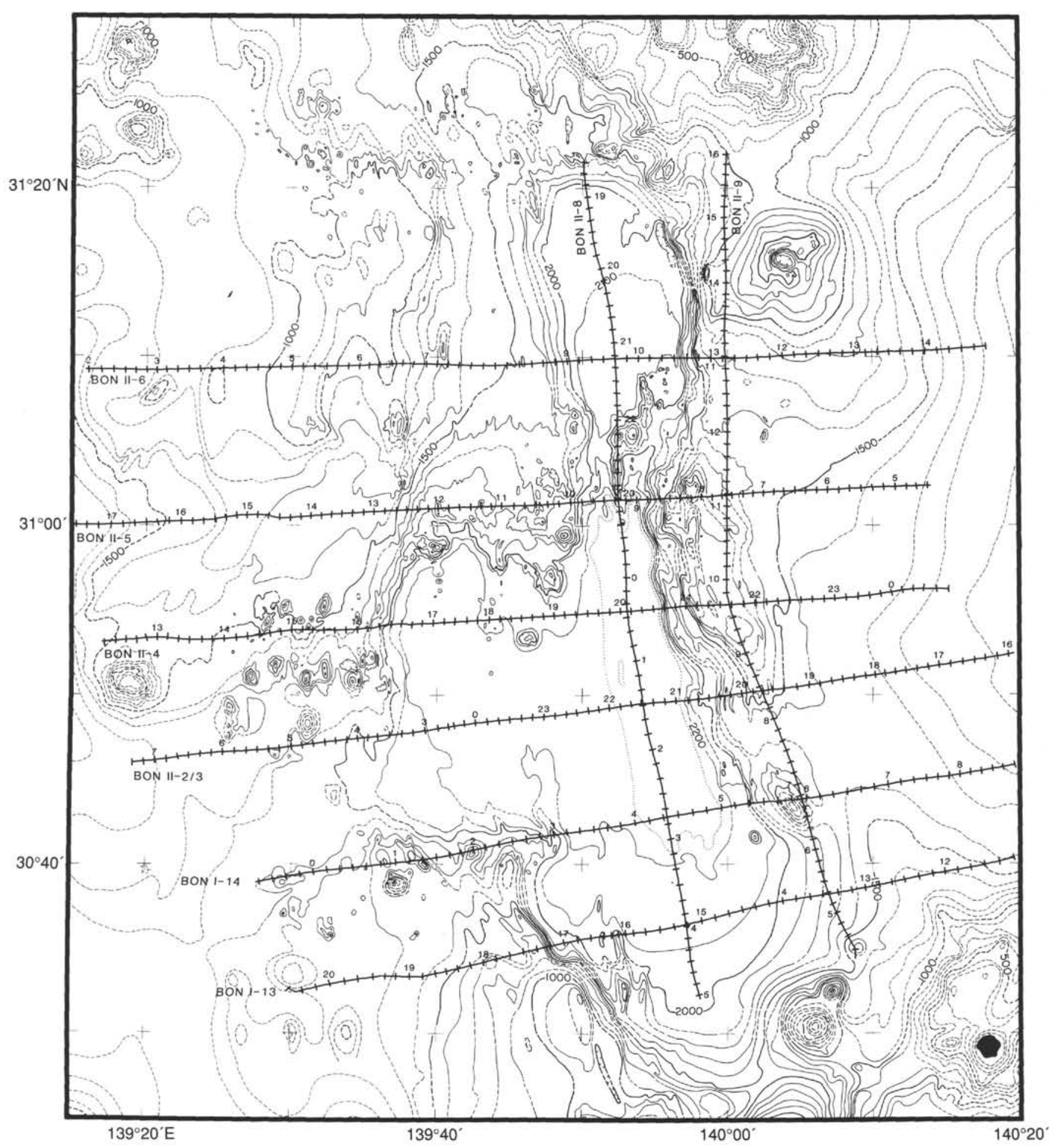

Figure 7. Detailed track chart of Fred Moore cruises 3505 (BON I) and 3507 (BON II) in the area of the Sumisu Rift. The contour interval is $100 \mathrm{~m}$. 

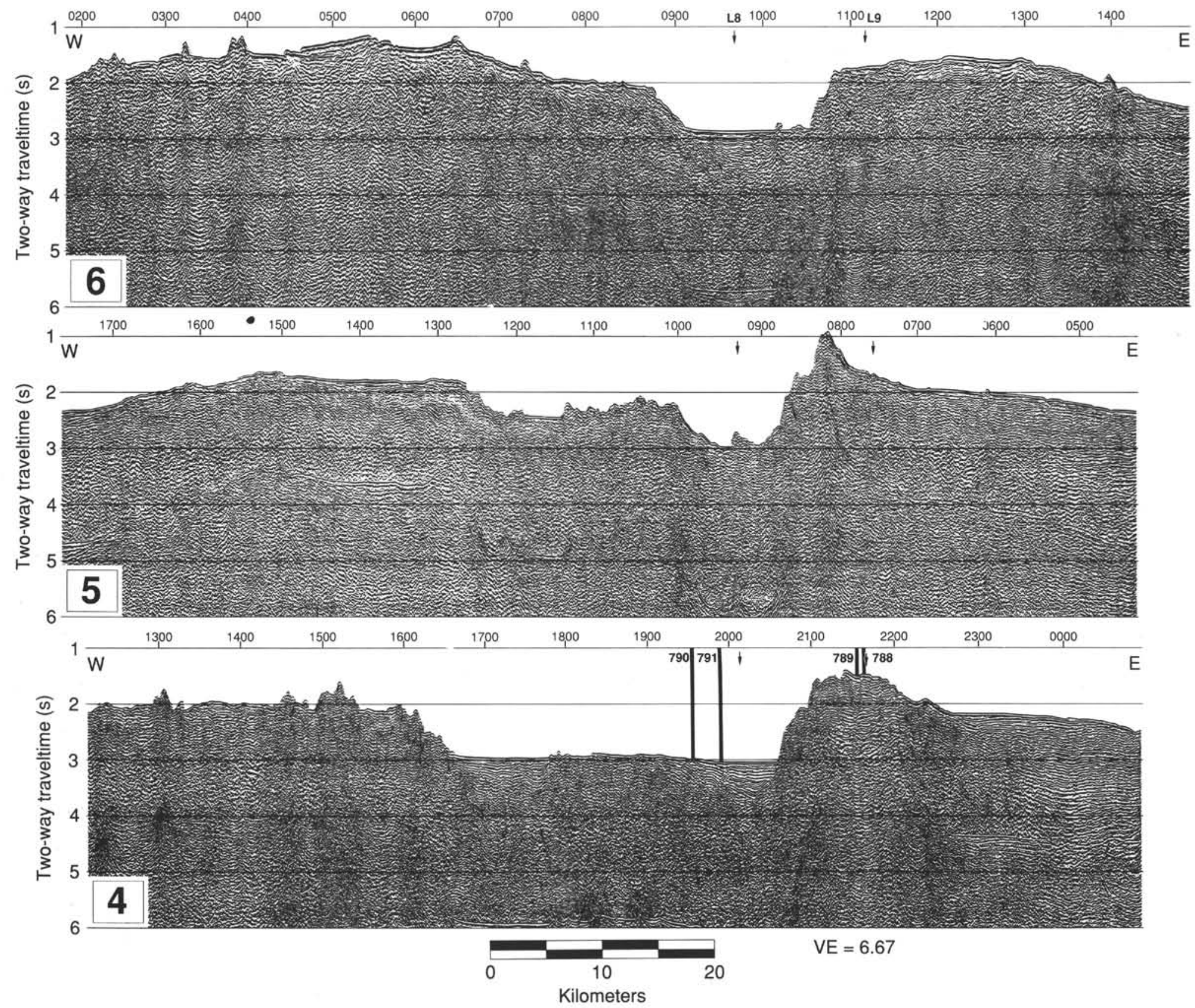

$\mathrm{VE}=6.67$ 

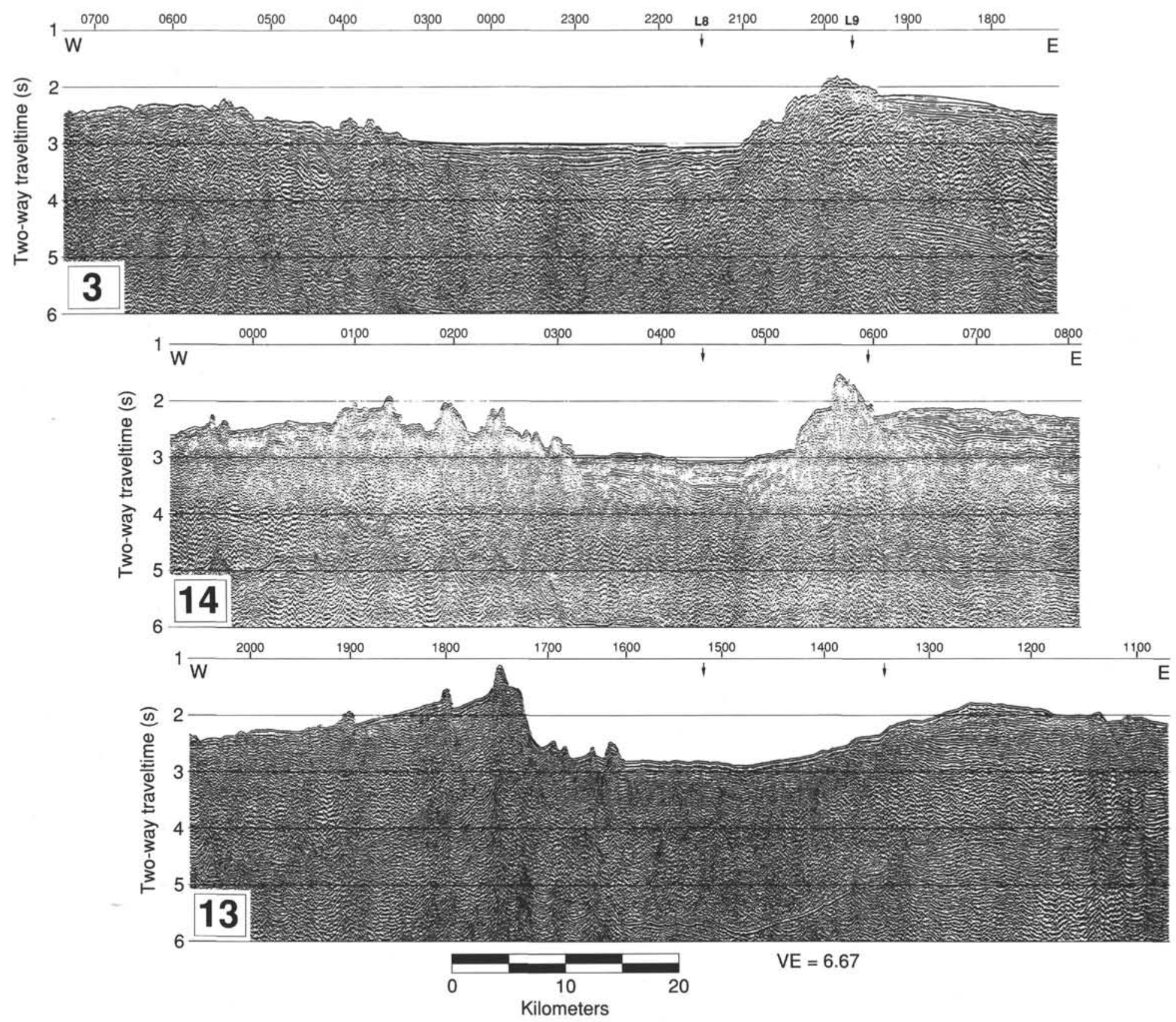

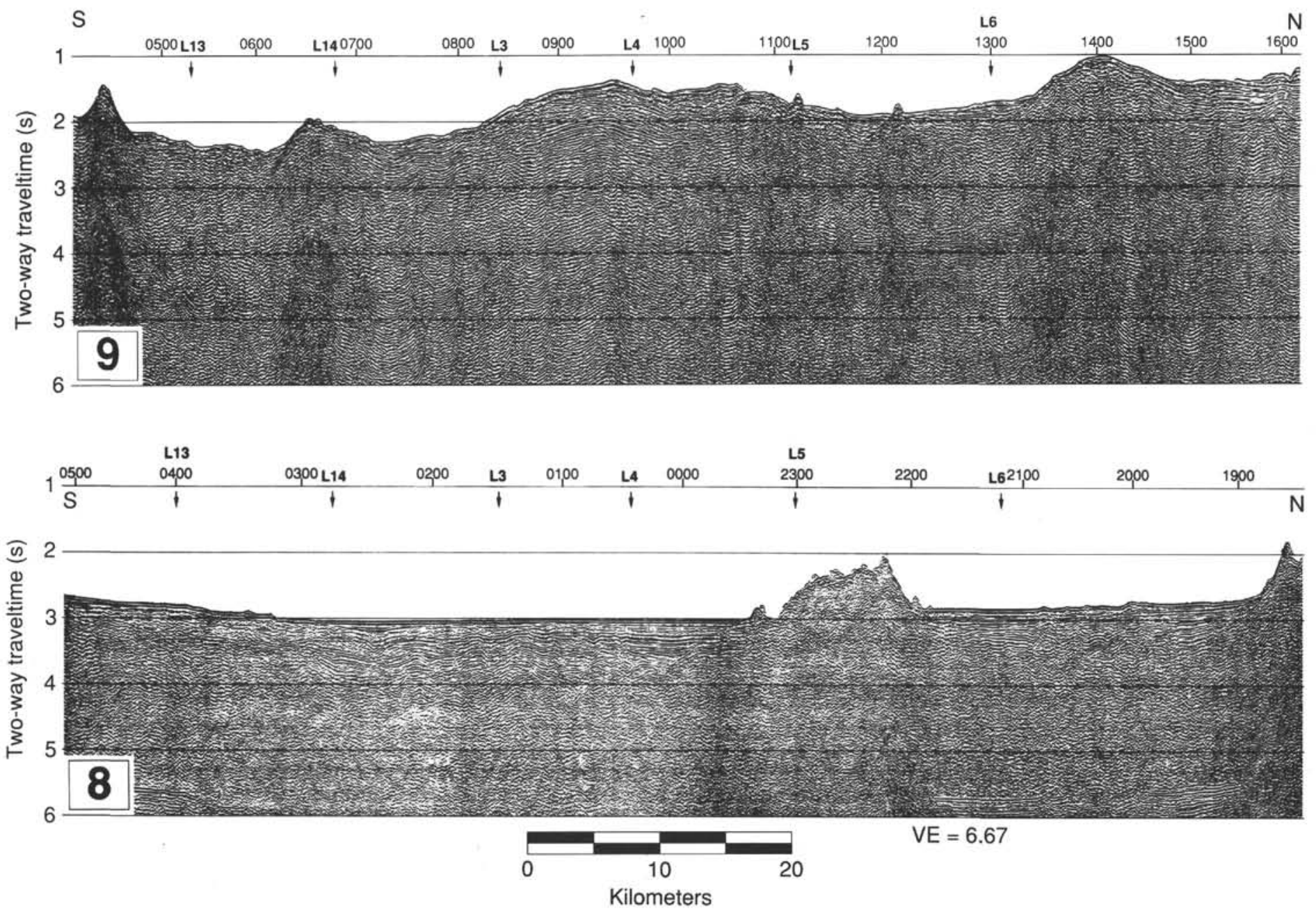

Figure 9. MCS Profiles 8 (along the axis) and 9 (along the arc margin) of the Sumisu Rift. See Figure 7 for location. 